\title{
Spectroscopic characterization of chloride and pseudohalide ruthenium(II) complexes with 4-(4-nitrobenzyl)pyridine
}

\author{
Anna M. Maroń · Jan G. Małecki
}

Received: 29 May 2014/ Accepted: 28 July 2014/Published online: 17 August 2014

(C) The Author(s) 2014. This article is published with open access at Springerlink.com

\begin{abstract}
Chloride, isocyanate and isothiocyanate hydride carbonyl ruthenium(II) complexes of 4-(4-nitrobenzyl)pyridine were synthesized from the precursor complex [Ru$\mathrm{HCl}(\mathrm{CO})\left(\mathrm{PPh}_{3}\right)_{3}$ ] and characterized by IR, NMR, UV-Vis spectroscopy and X-ray crystallography. The electronic structures of the complexes were investigated by means of DFT calculations, based on their crystal structures. The spinallowed singlet-singlet electronic transitions of the complexes were calculated by time-dependent DFT, and the UVVis spectra are discussed on this basis. The emission properties of the complexes were studied at ambient temperature, and the quantum yields of fluorescence, the lifetimes and nature of the excited states are discussed. The chloride and isothiocyanate complexes are practically nonemissive, with quantum yields under $0.01 \%$. Interpretation of spectra, supported by TD-DFT calculations, indicates that in this energy region, the transitions have MLCT character with admixture of LLCT (chloride and isothiocyanate complexes). The dominant LLCT character was visible in the case of the most emissive (isocyanate) complex. The low values of the lifetimes and quantum yields for these complexes indicate the influence of the metal center in the emission process.
\end{abstract}

Electronic supplementary material The online version of this article (doi:10.1007/s11243-014-9865-2) contains supplementary material, which is available to authorized users.

A. M. Maroń $(\bowtie) \cdot$ J. G. Małecki

Department of Crystallography, Institute of Chemistry, University of Silesia, ul. Szkolna 9, 40-006 Katowice, Poland e-mail: ank806@wp.pl

\section{Introduction}

Luminescent ruthenium(II) complexes are of interest of due to their applications in photochemical molecular devices (PMD) such as OLED devices, dye-sensitized solar cells (DSSC), photosensitizers in artificial photosynthesis, sensors, DNA dynamic probes, lipid probes and fluorescence polarization immunoassays (FPI) [1-11]. Recent descriptions of the photochemistry of coordination compounds of ruthenium(II) indicate that they can fulfill many of the functions necessary for these devices [1]. One of the most studied classes of ruthenium(II) complexes are polypyridine complexes [11-15]. In these species, strong emission in ambient temperature solutions is attributed to ${ }^{3}$ MLCT states, but the photophysics and photochemistry of cationic polypyridine complexes depend also on the accessibility of short lived ( $\tau=5-20 \mathrm{~ns}$ or less) ${ }^{3} \mathrm{MC}$ states [1]. However, the coordination environments of this metal based on the precursor complex $\left[\mathrm{RuHCl}(\mathrm{CO})\left(\mathrm{PPh}_{3}\right)_{3}\right]$ have been little described with respect to their photophysical and photochemical properties. Phosphine complexes of ruthenium(II) based on $\left[\mathrm{RuHCl}(\mathrm{CO})\left(\mathrm{PPh}_{3}\right)_{3}\right]$ have recently been studied as effective and selective catalysts in organic synthesis, but are much less known as luminophores.

It is well know that the spectroscopic properties of ruthenium(II) complexes can be tuned by the introduction of appropriate ligands. On the one hand, $N$-heterocyclic $\pi$ acceptor ligands determine the character of the unoccupied LUMO orbital. On the other hand, it is known that pseudohalide ligands tune the $t_{2 \mathrm{~g}}$ ruthenium orbitals by distributing the $4 d_{\mathrm{Ru}}$ energy levels over a wide energy range, due to mixing with orbitals centered on the thiocyanate (NCS) ligand [15-17]. Thus, studies of the electronic structures of these complexes are an important area of chemistry. In our recent studies on hydride carbonyl 
complexes with $\mathrm{N}, \mathrm{O}$-donor ligands, we also observed the influences of triphenylphosphine and carbonyl ligands on their fluorescent properties [18, 19].

In this work, we present the synthesis, and characterization of ruthenium(II) hydride-carbonyl chloride, cyanate and isothiocyanate complexes with 4-(4-nitrobenzyl)-pyridine as co-ligand. It is known that free 4-(4-nitrobenzyl)-pyridine itself is nonemissive, but coordination leads to complexes with LUMOs dominated by $\pi^{*}$ orbitals of the pyridine derivative. The character of the excited states of the complexes depends mostly on effects of the halide $\left(\mathrm{Cl}^{-}\right)$or pseudohalide $\left(\mathrm{SCN}^{-}, \mathrm{NCO}^{-}\right)$ligands on the HOMO. Characterization of the complexes by X-ray crystallography and IR, NMR, and absorption and emission UV-Vis spectroscopy are complemented by theoretical calculations with the use of DFT. The quantum chemical study included the characterization of the molecular and electronic structures of the complexes by analysis of optimized molecular geometries. Finally, time-dependent density functional theory (TD-DFT) was used to calculate the electronic absorption spectra. Based on a molecular orbital scheme, these results allowed for the interpretation of the experimental UV-Vis spectra. The fluorescence properties (spectra, quantum yields, lifetime) are used to characterize the excited states.

\section{Experimental}

All reagents used for the syntheses were commercially available and used without further purification. The starting complex $\left[\mathrm{RuHCl}(\mathrm{CO})\left(\mathrm{PPh}_{3}\right)_{3}\right]$ was synthesized according to the literature method [20].

Synthesis of the complexes

These complexes were synthesized by the reaction of [Ru$\left.\mathrm{HCl}(\mathrm{CO})\left(\mathrm{PPh}_{3}\right)_{3}\right] \quad\left(0.2 \mathrm{~g}, 2 \times 10^{-4} \mathrm{~mol}\right), \quad 4$-(4-nitrobenzyl)pyridine $\left(0.047 \mathrm{~g}, 2.2 \times 10^{-4} \mathrm{~mol}\right)(\mathbf{1})$, sodium cyanate $\left(0.016 \mathrm{~g}, 2.2 \times 10^{-4} \mathrm{~mol}\right)(\mathbf{2})$, or ammonium thiocyanate $\left(0.014 \mathrm{~g}, 2.2 \times 10^{-4} \mathrm{~mol}\right)(3)$ in methanol $(100 \mathrm{~mL})$. The reaction mixture was refluxed for $6 \mathrm{~h}$. After this time, it was cooled and filtered. Crystals suitable for X-ray crystal analysis were obtained by slow evaporation of the reaction mixtures.

\section{$\left[\mathrm{RuHCl}(\mathrm{CO})\left(\mathrm{PPh}_{3}\right)_{2}\left(\mathrm{NO}_{2} \mathrm{PhCH}_{2} \mathrm{Py}\right)\right](\mathbf{1})$}

Yield $58 \% . \mathrm{C}_{49} \mathrm{H}_{41} \mathrm{ClN}_{2} \mathrm{P}_{2} \mathrm{Ru}$. Anal. calc: $\mathrm{C} 68.7 \mathrm{H} 4.8 \mathrm{~N}$ $3.3 \%$. Anal. found: C $68.7 \mathrm{H} 4.9$ N $3.3 \%$. IR ( $\mathrm{KBr}$; $\left.\mathrm{cm}^{-1}\right): 3,053 v_{(\mathrm{ArH})} ; 2,051,2,017 v_{(\mathrm{Ru}-\mathrm{H})} ; 1,919 v_{(\mathrm{CO})}$; $1,594 v_{(\text {asym NO2) }} ; 1,480 \delta_{(\mathrm{C}-\mathrm{CH}}$ out of the plane) $; 1,432$ $v_{\mathrm{Ph}(\mathrm{P}-\mathrm{Ph})} ; 1,343 v_{(\mathrm{sym} \mathrm{NO})} ; 1,091 \delta_{(\mathrm{C}-\mathrm{CH}}$ in the plane) $; 743$ $\delta_{(\mathrm{C}-\mathrm{C} \text { out of the plane) }} ; 693 \delta_{(\mathrm{C}-\mathrm{C} \text { in the plane })} ; 518 v_{(\mathrm{N} ; \mathrm{P}-\mathrm{Ru})}$. ${ }^{1} \mathrm{H}$ NMR $\left(500 \mathrm{MHz}, \mathrm{CDCl}_{3}\right) \delta 8.30-8.12\left(\mathrm{~m}\right.$, pybenzylNO$\left.{ }_{2}\right)$,
7.85-7.36 (m, pybenzylNO $\left.{ }_{2}\right), \quad 7.36-7.12\left(\mathrm{~m}, \mathrm{PPh}_{3} / \mathrm{py}-\right.$ benzylNO $\left.\mathrm{N}_{2}\right), 4.06\left(\mathrm{~s}, \mathrm{CH}_{2}\right.$ from pybenzylNO $\left.{ }_{2}\right),-13.50(t$, $\left.J=19.6 \mathrm{~Hz}, \mathrm{H}_{(\mathrm{Ru})}\right) .{ }^{31} \mathrm{P}$ NMR $\left(202 \mathrm{MHz}, \mathrm{CDCl}_{3}\right) \delta 45.57$ $\left(\mathrm{d}, J=6.4 \mathrm{~Hz}, \mathrm{PPh}_{3}\right),{ }^{13} \mathrm{C}$ NMR $\left(126 \mathrm{MHz}, \mathrm{CDCl}_{3}\right) \delta$ 204.18 (s), 153.90 (s), 152.47 (d, $J=7.3 \mathrm{~Hz}), 149.79$ (s), 149.55 (s), 147.08 (d, $J=4.5 \mathrm{~Hz}), 145.52(\mathrm{~s}), 145.32$ (s), 136.43-133.77 (m), 133.55 (d, $J=9.8 \mathrm{~Hz}), 132.98$ (s), 132.67-131.93 (m), 129.88 (s), 129.34 (s), 128.52 (d, $J=12.1 \mathrm{~Hz}), 128.15(\mathrm{~s}), 127.67(\mathrm{~d}, J=10.1 \mathrm{~Hz}), 40.48(\mathrm{~s})$. UV-Vis (methanol) (nm $(\log \varepsilon)$ ): 330.4 (3.50), 267.4 (4.31), 209.6 (4.92).

\section{$\left[\mathrm{RuH}(\mathrm{NCO})(\mathrm{CO})\left(\mathrm{PPh}_{3}\right)_{2}\left(\mathrm{NO}_{2} \mathrm{PhCH}_{2} \mathrm{py}\right)\right]$ (2)}

Yields $54 \%$. $\mathrm{C}_{50} \mathrm{H}_{41} \mathrm{~N}_{3} \mathrm{O}_{4} \mathrm{P}_{2}$ Ru. Anal. calc. C $65.9 \mathrm{H} 4.5 \mathrm{~N}$ $4.6 \%$. Anal. found. C $65.6 \mathrm{H} 4.6 \mathrm{~N} 4.6 \%$. IR: $3,056 v_{(\mathrm{ArH})}$; $2,234 v_{(\mathrm{N}=\mathrm{C} \text { from } \mathrm{NCO})} ; 1,992,1,971 v_{(\mathrm{Ru}-\mathrm{H})} ; 1,928 v_{(\mathrm{CO})}$; $1,597 v_{\text {(asym NO2) }} ; 1,479 \delta_{(\mathrm{C}-\mathrm{CH} \text { out of the plane) }} ; 1,433 v_{\mathrm{Ph}(\mathrm{P}-\mathrm{Ph})}$; $1,347 v_{(\mathrm{sym} \mathrm{NO} 2)} ; 1,330 v_{(\mathrm{CO} \text { from NCO})} ; 1,090 \delta_{(\mathrm{C}-\mathrm{CH}}$ in the plane); $741 \delta_{(\mathrm{C}-\mathrm{C} \text { out of the plane) }} ; 693 \delta_{(\mathrm{C}-\mathrm{C} \text { in the plane })} ; 602 \delta_{(\mathrm{NCO})}$; $518 v_{(\mathrm{N} ; \mathrm{P}-\mathrm{Ru})} \cdot{ }^{1} \mathrm{H}$ NMR $\left(400 \mathrm{MHz}, \mathrm{CDCl}_{3}\right) \delta 8.34-8.17(\mathrm{~m}$, pybenzylNO $\left.{ }_{2}\right), 7.62-7.50\left(\mathrm{~m}\right.$, pybenzylNO $\left.{ }_{2}\right), 7.39-7.09(\mathrm{~m}$, pybenzylNO ${ }_{2}, \mathrm{PPh}_{3}$ ), 7.07-6.97 (m, pybenzylNO $\left.\mathrm{N}_{2}\right), 3.85(\mathrm{~s}$, $\mathrm{CH}_{2}$ from pybeznylNO $\left.\mathrm{N}_{2}\right),-7.11(\mathrm{dt}, J=103.6,24.5 \mathrm{~Hz}$, $\left.\mathrm{H}_{(\mathrm{Ru})}\right) .{ }^{31} \mathrm{P}$ NMR $\left(202 \mathrm{MHz}, \mathrm{CDCl}_{3}\right) \delta 45.49\left(\mathrm{~s}, \mathrm{PPh}_{3}\right)$. ${ }^{13} \mathrm{C}$ NMR (101 MHz, $\mathrm{CDCl}_{3}$ ) $\delta 207.04(\mathrm{~s}), 152.67$ (s), 134.17 $(\mathrm{d}, J=5.6 \mathrm{~Hz}), 133.85(\mathrm{~d}, J=6.9 \mathrm{~Hz}), 129.70(\mathrm{~s}), 129.32$ $(\mathrm{d}, J=9.9 \mathrm{~Hz}), 128.98$ (s), $127.79(\mathrm{dt}, J=12.5,4.7 \mathrm{~Hz})$, $123.95(\mathrm{~d}, J=5.3 \mathrm{~Hz}), 40.48$ (s). UV-Vis (methanol) (nm (loge)): 337.0 (4.26), 275.8 (4.86), 252.4 (5.02), 226.8 (5.27), 207.6 (5.62).

\section{$\left[\mathrm{RuH}(\mathrm{NCS})(\mathrm{CO})\left(\mathrm{PPh}_{3}\right)_{2}\left(\mathrm{NO}_{2} \mathrm{PhCH}_{2} \mathrm{py}\right)\right]$ (3)}

Yield $63 \% . \mathrm{C}_{50} \mathrm{H}_{41} \mathrm{~N}_{3} \mathrm{O}_{3} \mathrm{P}_{2}$ RuS. Anal. calc. C $64.8 \mathrm{H} 4.5 \mathrm{~N}$ $4.5 \%$. Anal. found. C $64.6 \mathrm{H} 4.5 \mathrm{~N} 4.5 \%$. IR: 3,055 $v_{(\mathrm{ArH})}$; $2,094 v_{(\mathrm{N}=\mathrm{C}}$ from NCS $; 2,006 v_{(\mathrm{Ru}-\mathrm{H})} ; 1,925 v_{(\mathrm{CO})} ; 1,597$ $v_{\text {(asym NO2) }} ; 1,479 \delta_{(\mathrm{C}-\mathrm{CH} \text { out of the plane) }} ; 1,432 v_{\mathrm{Ph}(\mathrm{P}-\mathrm{Ph})} ; 1,347$ $v_{(\mathrm{sym} \mathrm{NO})} ; 1,090 \delta_{(\mathrm{C}-\mathrm{CH}}$ in the plane) $; 742 \delta_{(\mathrm{C}-\mathrm{C} \text { out of the plane) }}$; $694 \delta_{(\mathrm{C}-\mathrm{C}}$ in the plane) $; 518 v_{(\mathrm{N} ; \mathrm{P}-\mathrm{Ru})} \cdot{ }^{1} \mathrm{H}$ NMR $(400 \mathrm{MHz}$, $\left.\mathrm{CDCl}_{3}\right) \delta 8.29-8.20\left(\mathrm{~m}\right.$, pybenzylNO ${ }_{2}$ ), 7.59-7.47 (m, pybenzylNO $\left.\mathrm{N}_{2}\right), 7.38-7.10\left(\mathrm{~m}, \mathrm{PPh}_{3}\right.$, pybenzylNO $\left.\mathrm{N}_{2}\right), 7.05(\mathrm{dd}$, $J=11.4,4.1 \mathrm{~Hz}$, pybenzylNO $\left.\mathrm{N}_{2}\right), 6.96(\mathrm{t}, J=8.6 \mathrm{~Hz}$, pybenzylNO2), 3.87 (s, $\mathrm{CH}_{2}$ from pybenzylNO ${ }_{2}$ ), $-7.18(\mathrm{dt}$, $\left.J=100.0,24.4 \mathrm{~Hz}, \mathrm{H}_{(\mathrm{Ru})}\right) \cdot{ }^{31} \mathrm{P}$ NMR $\left(162 \mathrm{MHz}, \mathrm{CDCl}_{3}\right) \delta$ $39.42\left(\mathrm{~d}, J=15.5 \mathrm{~Hz}, \mathrm{PPh}_{3}\right) \cdot{ }^{13} \mathrm{C} \mathrm{NMR}\left(101 \mathrm{MHz}, \mathrm{CDCl}_{3}\right)$ $\delta 206.92(\mathrm{~s}), 152.72(\mathrm{~s}), 134.77(\mathrm{~d}, J=22.4 \mathrm{~Hz}), 134.12(\mathrm{t}$, $J=5.9 \mathrm{~Hz}), 133.95-133.66(\mathrm{~m}), 133.42(\mathrm{~d}, J=7.5 \mathrm{~Hz})$, $129.72 \quad(\mathrm{~s}), \quad 129.49 \quad(\mathrm{~d}, \quad J=6.5 \mathrm{~Hz}), \quad 129.14 \quad(\mathrm{~s})$, 128.54-127.41 (m), 124.28 (s), 123.98 (s), 40.50 (s). UVVis (methanol) $(\mathrm{nm}(\log \varepsilon)): 327.5$ (4.43), 278.0 (4.81), 208.0 (5.68). 
Physical measurements

Infrared spectra were recorded on a Nicolet iS5 FTIR spectrophotometer in the range 4,000-400 $\mathrm{cm}^{-1}$ using $\mathrm{KBr}$ pellets. Electronic spectra were measured on a Jasco V630 UV-VIS spectrophotometer in the range of 600-180 $\mathrm{nm}$ in methanol solutions. The ${ }^{1} \mathrm{H},{ }^{31} \mathrm{P}$ and ${ }^{13} \mathrm{C}$ NMR spectra were obtained at room temperature in $\mathrm{CDCl}_{3}$ using a Bruker $500 \mathrm{MHz}$ spectrometer. The ${ }^{13} \mathrm{C}$ NMR spectra was prepared as proton decoupled ${ }^{13} \mathrm{C}\left\{{ }^{1} \mathrm{H}\right\}$ spectra. Elemental analyses (C, H, N) were obtained on a Perkin-Elmer CHN-2400 analyzer. Powder X-ray diffraction (PXRD) measurements were performed on a PANalytical Empyrean X-ray diffractometer using $\mathrm{Cu}-\mathrm{K} \alpha$ radiation $(\lambda=1.5418 \AA)$, in which the X-ray tube was operated at $40 \mathrm{kV}$ and $30 \mathrm{~mA}$ ranging from $5^{\circ}$ to $80^{\circ}$ (Supplementary Materials. Figure $\mathrm{S} 1)$. The steady-state and time-resolved emission spectra were measured for EtOH:MeOH (4:1) solutions with a FLS980 spectrophotometer at ambient temperature using a 450-W Xe arc lamp as a light source and PMT + $500 \mathrm{~nm}$ (Hamamatsu, R928P) in cooled housing as a detector. The Raman scattering of the solvent was always subtracted from the steady-state emission spectra of the complexes. The quantum yields of fluorescence were determined by absolute methods at room temperature, using the integrating sphere with solvent as a blank. The solutions of samples were first filtered and diluted to absorbance under 0.1 to avoid inner filter effects and the influence of impurities from the medium, then excited at the wavelength corresponding to the excitation maximum of the complexes. The timeresolved measurements were made in optically diluted $(0.05<$ O.D < 0.1$)$ methanol: ethanol solutions at room temperature using time correlated single photon counting (TCSPC) methods on an FLS-980 spectrophotometer. The excitation wavelength $(310 \mathrm{~nm})$ was obtained using a picosecond pulsed diode EPLED-310 nm with $100 \mathrm{~ns}$ pulse period as light source. A PMT $+500 \mathrm{~nm}$ (Hamamatsu, $\mathrm{R} 928 \mathrm{P}$ ) in cooled housing was used as detector. The system was aligned at the emission wavelengths. Additionally, for the analysis of fluorescence decay, an instrument response function (IRF) needs to be obtained. The IRF contains information about the time response of the overall optical and electronic system. The IRF was designated using ludox solution as a standard at $310 \mathrm{~nm}$. The influence of Raman scattering of the solvent on emission of the sample was avoided using a filter.

\section{Computational methods}

The calculations were carried out using the Gaussian09 [21] program. Molecular geometries of the singlet ground states of the complexes were fully optimized in the gas phase at the B3LYP level of theory $[22,23]$. For each of the complexes, a frequency calculation was carried out, verifying that the optimized molecular structure corresponds to an energy minimum; thus, only positive frequencies were found. The DZVP basis set [24] with $f$ functions with exponents 1.94722036 and 0.748930908 was used to describe the ruthenium atom, and the basis set used for the lighter atoms $(\mathrm{C}, \mathrm{N}, \mathrm{O}, \mathrm{S}, \mathrm{P}, \mathrm{H})$ was $6-31 \mathrm{G}$ with a set of $d$ and $p$ polarization functions $(6-31 G(2 d, p)$ for sulfur, 6-31G** for carbon, nitrogen, and 6-31G(d,p) for hydrogen). The TD-DFT method [25] was employed to calculate the electronic absorption spectra of the complexes using the solvent Polarizable Continuum Model (PCM). The contributions of various atom groups (ligands, metal center) to each molecular orbital were calculated using Mulliken population analysis. GaussSum 2.2 [26] was used to calculate group contributions to the molecular orbitals and to prepare the density of states (DOS) diagrams. The DOS diagrams were created by convoluting the molecular orbital information with Gaussian curves of unit height and FWHM (Full Width at Half Maximum) of $0.3 \mathrm{eV}$.

Crystal structure determination and refinement

Crystals of the complexes (1)-(3) were mounted in turn on a Gemini A Ultra Oxford Diffraction automatic diffractometer equipped with a CCD detector for data collection. $\mathrm{X}$-ray intensity data were collected with graphite monochromated $\operatorname{Mo} K_{\alpha}$ radiation $(\lambda=0.71073 \AA)$ at a temperature of $295(2) \mathrm{K}$, with $\omega$ scan mode. Ewald sphere reflections were collected up to $2 \theta=50.10^{\circ}$. Details concerning crystal data and refinement are gathered in Table 1. Lorentz, polarization and empirical absorption corrections using spherical harmonics implemented in the SCALE3 ABSPACK scaling algorithm [27] were applied. The structures were solved by the Patterson's method and subsequently completed by difference Fourier recycling. All the nonhydrogen atoms were refined anisotropically using full-matrix, least-squares techniques. All hydrogen atoms except $\mathrm{H}(\mathrm{Ru})$ were positioned in geometrically idealized positions and were allowed to ride on their parent atoms with $\mathrm{Uiso}(\mathrm{H})=1.2 \mathrm{Ueq}$. The $\mathrm{Ru}-\mathrm{H}$ hydrogen atoms were found from difference Fourier synthesis after four cycles of anisotropic refinement and refined as "riding" on the adjacent atom with an individual isotropic temperature factor equal to 1.2 times the value of the equivalent temperature factor of the parent atom, with geometry idealization after each cycle. Bearing in mind the limits of Fourier synthesis and the problems in recognizing artifacts in the immediate neighborhood of heavy atoms, it is doubtful if a reliable position for the hydrogen atom bound to the $\mathrm{Ru}$ atom can be found in the difference Fourier map whilst avoiding the danger of mistaking the effects of the 
Table 1 Crystal data and structure refinement details of $\left[\mathrm{RuHCl}(\mathrm{CO})\left(\mathrm{NO}_{2} \mathrm{PhCH}_{2} \mathrm{py}\right)\left(\mathrm{PPh}_{3}\right)_{2}\right](\mathbf{1}),\left[\mathrm{RuH}(\mathrm{NCO})(\mathrm{CO})\left(\mathrm{NO}_{2} \mathrm{PhCH} \mathrm{Phy}_{2}\left(\mathrm{PPh}_{3}\right)_{2}\right](\mathbf{2})\right.$ and $\left[\mathrm{RuH}(\mathrm{NCS})(\mathrm{CO})\left(\mathrm{NO}_{2} \mathrm{PhCH}_{2} \mathrm{py}\right)\left(\mathrm{PPh}_{3}\right)_{2}\right](3)$

\begin{tabular}{|c|c|c|c|}
\hline & 1 & 2 & 3 \\
\hline Empirical formula & $\mathrm{C}_{49} \mathrm{H}_{41} \mathrm{CLN}_{2} \mathrm{O}_{3} \mathrm{P}_{2} \mathrm{Ru}$ & $\mathrm{C}_{50} \mathrm{H}_{41} \mathrm{~N}_{3} \mathrm{O}_{4} \mathrm{P}_{2} \mathrm{Ru}$ & $\mathrm{C}_{50} \mathrm{H}_{41} \mathrm{~N}_{3} \mathrm{O}_{3} \mathrm{P}_{2} \mathrm{RuS}$ \\
\hline Formula weight & 904.30 & 910.87 & 926.93 \\
\hline Temperature $(\mathrm{K})$ & 295.0(2) K & 295.0(2) K & 295.0(2) K \\
\hline Crystal system & Monoclinic & Monoclinic & Triclinic \\
\hline Space group & $P 2{ }_{1} / \mathrm{c}$ & $P 2_{1} / \mathrm{c}$ & $P-1$ \\
\hline \multicolumn{4}{|l|}{ Unit cell dimensions } \\
\hline a $(\AA)$ & $9.6791(4)$ & $10.1700(5)$ & $9.8744(14)$ \\
\hline $\mathrm{b}(\AA)$ & $38.6997(13)$ & $22.5135(8)$ & $9.9679(9)$ \\
\hline c $(\AA)$ & $35.4623(16)$ & 19.6361(14) & $23.4817(19)$ \\
\hline$\alpha\left({ }^{\circ}\right)$ & 90 & 90 & $99.318(7)$ \\
\hline$\beta\left({ }^{\circ}\right)$ & $96.626(5)$ & $104.934(6)$ & $101.484(9)$ \\
\hline$\gamma\left({ }^{\circ}\right)$ & 90 & 90 & $90.555(9)$ \\
\hline Volume $\left(\AA^{3}\right)$ & 13194.7(9) & 4344.1(4) & $2233.0(4)$ \\
\hline$Z$ & 12 & 4 & 2 \\
\hline Calculated density $\left(\mathrm{Mg} / \mathrm{m}^{3}\right)$ & 1.366 & 1.393 & 1.379 \\
\hline Absorption coefficient $\left(\mathrm{mm}^{-1}\right)$ & 0.533 & 0.483 & 0.515 \\
\hline $\mathrm{F}(000)$ & 5568 & 1872 & 952 \\
\hline Crystal dimensions (mm) & $0.27 \times 0.15 \times 0.08$ & $0.17 \times 0.11 \times 0.05$ & $0.46 \times 0.08 \times 0.05$ \\
\hline$\theta$ Range for data collection $\left({ }^{\circ}\right)$ & $3.29-25.05$ & $3.35-25.05$ & $3.45-25.05$ \\
\hline Index ranges & $\begin{array}{l}-11 \leq \mathrm{h} \leq 11 \\
-46 \leq \mathrm{k} \leq 38 \\
-42 \leq 1 \leq 42\end{array}$ & $\begin{array}{l}-12 \leq \mathrm{h} \leq 10 \\
-21 \leq \mathrm{k} \leq 26 \\
-16 \leq 1 \leq 23\end{array}$ & $\begin{array}{l}-11 \leq \mathrm{h} \leq 11 \\
-11 \leq \mathrm{k} \leq 11 \\
-27 \leq 1 \leq 27\end{array}$ \\
\hline Reflections collected & 57,882 & 18,391 & 20,738 \\
\hline Independent reflections & $23,344[R($ int $)=0.0886]$ & $7,664[R($ int $)=0.0589]$ & $7,894[R($ int $)=0.0393$ \\
\hline Data/restraints/parameters & $23,344 / 0 / 1579$ & $7,664 / 0 / 545$ & $7,894 / 0 / 545$ \\
\hline Goodness-of-fit on $F^{2}$ & 0.959 & 0.959 & 1.041 \\
\hline Final $R$ indices $[I>2 \sigma(\mathrm{I})]$ & $\begin{array}{l}R_{1}=0.0698 \\
\mathrm{w} R_{2}=0.1251\end{array}$ & $\begin{array}{l}R_{1}=0.0552 \\
\mathrm{w} R_{2}=0.1116\end{array}$ & $\begin{array}{l}R_{1}=0.0436 \\
\mathrm{w} R_{2}=0.0967\end{array}$ \\
\hline$R$ indices (all data) & $\begin{array}{l}R_{1}=0.1478 \\
\mathrm{w} R_{2}=0.1544\end{array}$ & $\begin{array}{l}R_{1}=0.1037 \\
\mathrm{w} R_{2}=0.1283\end{array}$ & $\begin{array}{l}R_{1}=0.0606 \\
\mathrm{w} R_{2}=0.1039\end{array}$ \\
\hline Largest diff. Peak and hole & 0.955 and -0.454 & 0.877 and -0.454 & 0.485 and -0.272 \\
\hline
\end{tabular}

series termination errors for a true atomic position. In the complexes, the $\mathrm{Ru}-\mathrm{H}$ bond lengths, ranging from 1.52(6) to 1.92(4) $\AA$, are acceptable. The OLEX2 [28] and SHELXS, SHELXL, SHELXH [29] programs were used for all the calculations. Atomic scattering factors were those incorporated in the computer programs.

The refinement of structure of (1) was difficult due to the large amount of atoms in the unit cell. The detected error resulted from distortion of a phenyl ring in $\mathrm{PPh}_{3}$ has no bearing on the bond lengths and angles around the metal center. On the other hand, the crystals used for measurements were very well formed and the X-ray measurements taken several times for different monocrystals gave the same parameters. Similarly, after the addition of distance restraints to the $\mathrm{C}-\mathrm{C}$ bonds (AFIX 66), the $R$ values were not significantly improved.

\section{Results and discussion}

In the reaction between $\left[\mathrm{RuHCl}(\mathrm{CO})\left(\mathrm{PPh}_{3}\right)_{3}\right]$ and 4-(4nitrobenzyl)pyridine $\left(\mathrm{NO}_{2} \mathrm{PhCH}_{2} \mathrm{py}\right)$, the chloride hydride carbonyl complex with formula $\left[\mathrm{RuHCl}(\mathrm{CO})\left(\mathrm{PPh}_{3}\right)_{2}\right.$ $\left(\mathrm{NO}_{2} \mathrm{PhCH}_{2}\right.$ py)] was obtained. The addition of stoichiometric amounts of cyanate or thiocyanate to the reaction mixture caused the removal of chloride from the coordination sphere and formation of complexes (2) and (3), respectively. 
The ${ }^{1} \mathrm{H}$ NMR spectra of the complexes present expected signals from the aromatic rings of $\mathrm{PPh}_{3}$ and 4-(4-nitrobenzyl)pyridine ligands. Moreover, the $\mathrm{CH}_{2}$ moiety from the benzyl group gave a singlet near to $4.00 \mathrm{ppm}$. The signals at high field indicate the presence of the hydride ligands and were observed as a triplet (1) at $-13.50 \mathrm{ppm}$ and doublet of triplets $(\mathbf{2}, \mathbf{3})$ at -7.11 and $-7.18 \mathrm{ppm}$, respectively. The differences in the shifts of these signals are due to differences between chloride and pseudohalide acceptor-donor properties. The ${ }^{31}$ P NMR spectra of the complexes (1) and (3) (unlike complex (2), which showed a singlet) both show doublets suggesting distortion from the ideal trans disposition of triphenylphosphine ligands. However, distortions from ideal octahedral geometries in each of these complexes are comparable $(\mathrm{P}(1)-\mathrm{Ru}(1)-\mathrm{P}(2)$ angles); thus, this situation can result from coupling to the hydride ligand. Additionally, in the case of complex (2), the observed $\pi-\pi$ stacking interactions between $\mathrm{PPh}_{3}$ phenyl centroids and pyridine ring of the ligand are stronger than in the other two complexes, which may explain the presence of a singlet on the ${ }^{31} \mathrm{P}$ spectrum. In the ${ }^{13} \mathrm{C}$ NMR spectra of the complexes, sets of signals coming from the pyridine and phenyl rings are visible in regions of $150-145$ and $130-123 \mathrm{ppm}$. A signal near to $40 \mathrm{ppm}$ results from the presence of a $-\mathrm{CH}_{2}-$ carbon in the ligand structure. The pseudohalide ligands in complexes (2) and (3) are indicated by strong $v_{\mathrm{N}=\mathrm{C}}$ stretching bands at 2,234 and $2,094 \mathrm{~cm}^{-1}$, respectively. For interpreting the vibrational spectra of complexes with ambidentate ligands such as thiocyanate, the wavenumber of $v_{\mathrm{C}=\mathrm{N}}$ is one of the factors that indicate the coordination mode. The complexes with N-bonded isothiocyanate ligands generally display the $\mathrm{C}=\mathrm{N}$ stretching band in a lower region (around 2,050 $\mathrm{cm}^{-1}$ ) than those with S-bonded thiocyanate (above $2,100 \mathrm{~cm}^{-1}$ ). Hence, complex (3) substantially fulfills this criterion. However, the frequency of this band is also sensitive to the co-ligands. Thus, in the determination of the coordination mode of thiocyanate ligands, $\mathrm{X}$-ray analysis is essential in most cases. The hydride and carbonyl ligands gave bands for $v_{\mathrm{Ru}-\mathrm{H}}$ and $v_{\mathrm{CO}}$ at 2,017, $1,919 \mathrm{~cm}^{-1}$ for (1), 1,971, 1,928 $\mathrm{cm}^{-1}$ for (2) and 2,006, $1,925 \mathrm{~cm}^{-1}$ for $(\mathbf{3})$. In the vibrational spectrum of the parent $\left[\mathrm{RuHCl}(\mathrm{CO})\left(\mathrm{PPh}_{3}\right)_{3}\right]$ complex, the $v_{\mathrm{Ru}-\mathrm{H}}$ and $v_{\mathrm{CO}}$ are visible at 2,020 and $1,922 \mathrm{~cm}^{-1}$, respectively. In the case of complexes (2) and (3), the influences of the coordinated pyridine rings are clearly visible in the decreasing frequencies of the $\mathrm{Ru}-\mathrm{H}$ stretching bands. The nitro group from 4-(4-nitrobenzyl)pyridine gave asymmetric stretching bands at 1,594, $1,597 \mathrm{~cm}^{-1}$ and symmetric stretches at 1,347, 1,343 $\mathrm{cm}^{-1}$.

Molecular structures

Crystals of the complexes (1)-(3) suitable for single-crystal $\mathrm{X}$-ray analyses were obtained by slow evaporation of the reaction mixtures. The crystals of complexes (1) and (2)

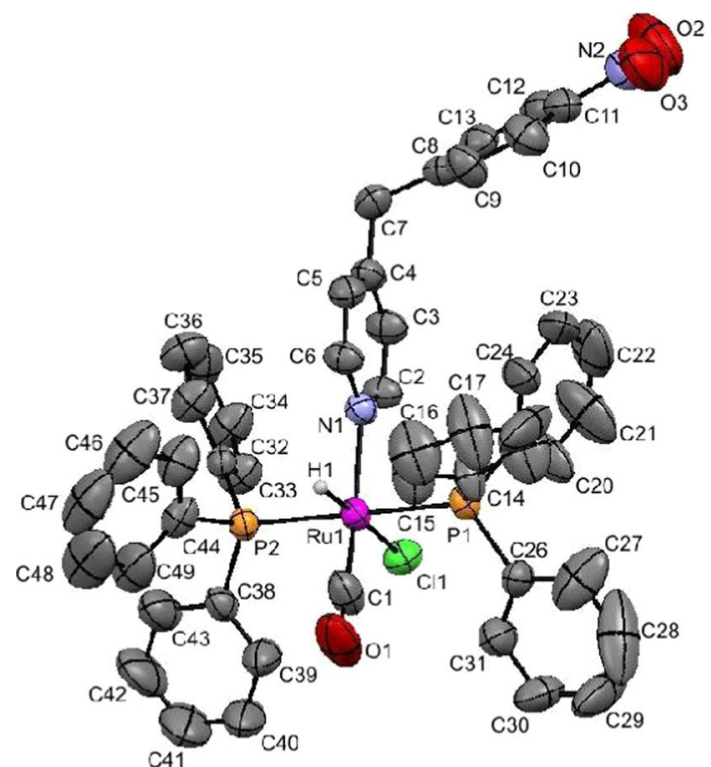

(1)

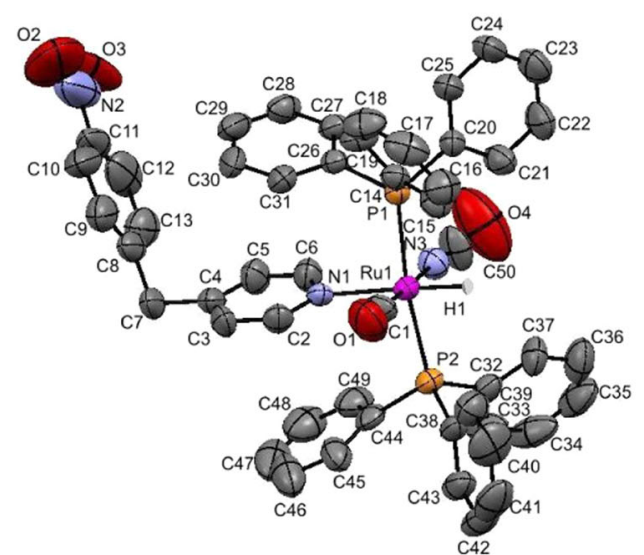

(2)

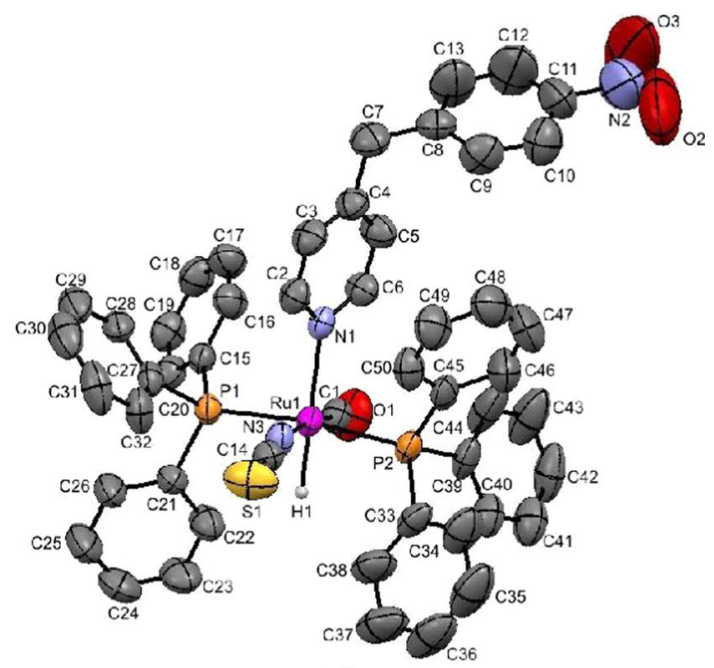

(3)

Fig. 1 Molecular structure of the (1), (2) and (3) complexes with $30 \%$ probability displacement ellipsoids. Hydrogen atoms (except $\mathrm{Ru}-\mathrm{H})$ are omitted for clarity 
Table 2 Selected experimental bond lengths $(\AA)$ and angles $\left(^{\circ}\right)$ for $\left[\left[\mathrm{RuHCl}(\mathrm{CO})\left(\mathrm{NO}_{2} \mathrm{PhCH}_{2}\right.\right.\right.$ py $\left.)\left(\mathrm{PPh}_{3}\right)_{2}\right](\mathbf{1}),\left[\mathrm{RuH}(\mathrm{NCO})(\mathrm{CO})\left(\mathrm{NO} \mathrm{NhCH}_{2}\right.\right.$ py) $\left.\left(\mathrm{PPh}_{3}\right)_{2}\right]$ (2) and $\left[\mathrm{RuH}(\mathrm{NCS})(\mathrm{CO})\left(\mathrm{NO}_{2} \mathrm{PhCH}_{2} \mathrm{py}\right)\left(\mathrm{PPh}_{3}\right)_{2}\right](\mathbf{3})$

\begin{tabular}{|c|c|c|c|c|c|}
\hline & (1) & & & (2) & (3) \\
\hline$(\AA)$ & $\operatorname{Ru}(1)$ & $\operatorname{Ru}(2)$ & $\operatorname{Ru}(3)$ & & \\
\hline $\mathrm{Ru}(1)-\mathrm{C}(1)$ & $1.790(8)$ & $1.823(8)[1.86]$ & $1.811(7)$ & $1.843(5)[1.86]$ & $1.823(3)[1.87]$ \\
\hline $\mathrm{Ru}(1)-\mathrm{N}(1)$ & $2.209(5)$ & $2.180(4)[2.27]$ & $2.185(4)$ & $2.232(4)[2.34]$ & $2.229(3)[2.34]$ \\
\hline $\mathrm{Ru}(1)-\mathrm{N}(3)$ & & & & $2.057(5)[2.13]$ & $2.094(3)$ [2.12] \\
\hline $\mathrm{Ru}(1)-\mathrm{P}(1)$ & $2.3553(16)$ & $2.3567(17)[2.43]$ & $2.3446(16)$ & $2.3515(12)[2.43]$ & $2.3622(8)[2.45]$ \\
\hline $\mathrm{Ru}(1)-\mathrm{P}(2)$ & $2.3438(16)$ & $2.3505(16)[2.44]$ & $2.3461(19)$ & $2.3478(13)[2.42]$ & $2.3565(9)[2.43]$ \\
\hline $\mathrm{Ru}(1)-\mathrm{H}(1)$ & $1.92(4)$ & $1.827(18)[1.61]$ & $1.52(6)$ & $1.64(3)[1.61]$ & $1.59(3)[1.60]$ \\
\hline $\mathrm{Ru}(1)-\mathrm{Cl}(1)$ & $2.5206(16)$ & $2.5256(16)[2.59]$ & $2.5305(16)$ & & \\
\hline $\mathrm{C}(1)-\mathrm{O}(1)$ & $1.158(8)$ & $1.140(8)[1.16]$ & $1.145(7)$ & $1.178(6)[1.17]$ & $1.138(4)[1.16]$ \\
\hline \multicolumn{6}{|l|}{$\left({ }^{\circ}\right)$} \\
\hline $\mathrm{C}(1)-\mathrm{Ru}(1)-\mathrm{N}(1)$ & $170.1(3)$ & $170.8(3)$ [171.18] & $169.2(2)$ & $90.9(2)[92.51]$ & $97.82(12)$ [96.30] \\
\hline $\mathrm{C}(1)-\mathrm{Ru}(1)-\mathrm{N}(3)$ & & & & $177.9(2)[178.32]$ & $172.88(13)[175.74]$ \\
\hline $\mathrm{C}(1)-\mathrm{Ru}(1)-\mathrm{P}(1)$ & $89.2(2)$ & $88.8(2)[88.14]$ & $90.2(2)$ & 89.91(16) [95.14] & $87.80(11)$ [91.84] \\
\hline $\mathrm{C}(1)-\mathrm{Ru}(1)-\mathrm{P}(2)$ & $89.9(2)$ & $90.8(2)$ [88.96] & $88.0(2)$ & $93.15(16)[90.18]$ & 92.11(11) [92.82] \\
\hline $\mathrm{N}(1)-\mathrm{Ru}(1)-\mathrm{P}(1)$ & $89.44(13)$ & $89.27(13)[90.98]$ & $89.13(14)$ & 94.01(10) [94.67] & $94.92(6)$ [93.19] \\
\hline $\mathrm{N}(1)-\mathrm{Ru}(1)-\mathrm{P}(2)$ & $91.03(13)$ & $90.87(12)[91.64]$ & 91.01(13) & $93.06(10)$ [94.12] & $92.43(6)[95.00]$ \\
\hline $\mathrm{N}(3)-\mathrm{Ru}(1)-\mathrm{P}(1)$ & & & & $88.53(12)$ [84.12] & 93.07(7) [88.07] \\
\hline $\mathrm{N}(3)-\mathrm{Ru}(1)-\mathrm{P}(2)$ & & & & 88.57(12) [90.79] & $86.12(7)$ [86.64] \\
\hline $\mathrm{P}(1)-\mathrm{Ru}(1)-\mathrm{P}(2)$ & $177.41(6)$ & $178.08(6)$ [176.69] & $171.32(6)$ & $172.25(5)[169.51]$ & $172.59(3)[170.08]$ \\
\hline $\mathrm{C}(1)-\mathrm{Ru}(1)-\mathrm{Cl}(1)$ & $99.8(3)$ & $99.6(3)$ [101.16] & $101.7(2)$ & & \\
\hline $\mathrm{N}(1)-\mathrm{Ru}(1)-\mathrm{Cl}(1)$ & $90.02(14)$ & $89.54(13)[87.65]$ & $88.95(13)$ & & \\
\hline $\mathrm{N}(1)-\mathrm{Ru}(1)-\mathrm{N}(3)$ & & & & 87.87(16) [86.05] & $89.15(10)$ [87.96] \\
\hline $\mathrm{P}(1)-\mathrm{Ru}(1)-\mathrm{Cl}(1)$ & $91.12(6)$ & $93.00(6)$ [93.20] & $97.05(6)$ & & \\
\hline $\mathrm{P}(2)-\mathrm{Ru}(1)-\mathrm{Cl}(1)$ & $91.43(6)$ & 88.92(5) [88.94] & $91.62(6)$ & & \\
\hline $\mathrm{C}(1)-\mathrm{Ru}(1)-\mathrm{H}(1)$ & $78.7(14)$ & $84.4(12)$ [86.43] & $85(2)$ & $89.5(9)[90.06]$ & $85.6(10)$ [86.35] \\
\hline $\mathrm{N}(1)-\mathrm{Ru}(1)-\mathrm{H}(1)$ & $91.5(13)$ & $86.7(12)[84.76]$ & $85(2)$ & 178.0(9) [177.39] & $176.2(10)[177.27]$ \\
\hline $\mathrm{N}(3)-\mathrm{Ru}(1)-\mathrm{H}(1)$ & & & & 91.8(9) [91.38] & 87.4(10) [89.40] \\
\hline $\mathrm{P}(1)-\mathrm{Ru}(1)-\mathrm{H}(1)$ & $90.7(13)$ & 91.4(13) [87.97] & $89(2)$ & $88.0(9)[85.54]$ & $87.0(10)$ [87.40] \\
\hline $\mathrm{P}(2)-\mathrm{Ru}(1)-\mathrm{H}(1)$ & $86.7(13)$ & $86.7(12)$ [90.25] & $82(3)$ & $84.9(9)[85.41]$ & 85.6(10) [84.17] \\
\hline $\mathrm{Cl}(1)-\mathrm{Ru}(1)-\mathrm{H}(1)$ & $177.6(12)$ & $174.2(11)[172.34]$ & $174(2)$ & & \\
\hline $\mathrm{Ru}(1)-\mathrm{C}(1)-\mathrm{O}(1)$ & $174.5(8)$ & $174.8(8)[176.22]$ & $174.8(6)$ & $175.3(5)[178.20]$ & 176.7(3) [178.80] \\
\hline $\mathrm{Ru}(1)-\mathrm{N}(3)-\mathrm{C}(50)$ & & & & $168.5(5)[160.72]$ & $170.5(3)[175.51]$ \\
\hline
\end{tabular}

Calculated values are given in square brackets

belong to the monoclinic $P 2_{1} / \mathrm{c}$ space group, whilst complex (3) crystallizes in the triclinic $P-1$ space group. In the structure of complex (1), three independent molecules exist in the asymmetric units. Figure 1 displays an ORTEP representation of one molecule of complex (1) and the molecular structures of (2) and (3); selected experimental bond distances and angles are collected in Table 2. The coordination environments around the ruthenium(II) centers in the complexes have distorted octahedral geometry, defined by two axial phosphorus donors from triphenylphoshine, plus hydride, carbonyl, halide and $\mathrm{NO}_{2} \mathrm{PhCH}_{2}$ py ligands in the equatorial plane. The bond distances and angles in the complexes are in good agreement with the reported data for similar complexes [30-33]. The angles between the two $\mathrm{PPh}_{3}$ ligands range from $175.6^{\circ}$ in (1, average value) to $172.25(5)^{\circ}$ in complex (2).

The main structural differences between these complexes are visible in the equatorial plane; in the chloride complex (1), a carbonyl ligand occupies the trans position relative to the $\mathrm{NO}_{2} \mathrm{PhCH}_{2}$ py ligand, while in the isocyanate and isothiocyanate complexes (2) and (3), the carbonyl is trans to the pseudohalide ligand. The carbonyl $\mathrm{C}(1)-\mathrm{O}(1)$ distance in complex (3) is shorter than those in (1) and (2), due to the enhanced $\mathrm{Ru}$ (II) $\rightarrow$ NCS backbonding via the involvement of the $\sigma$-donating and $\pi$-accepting carbonyl ligand trans to $\mathrm{NCS}^{-}$. 


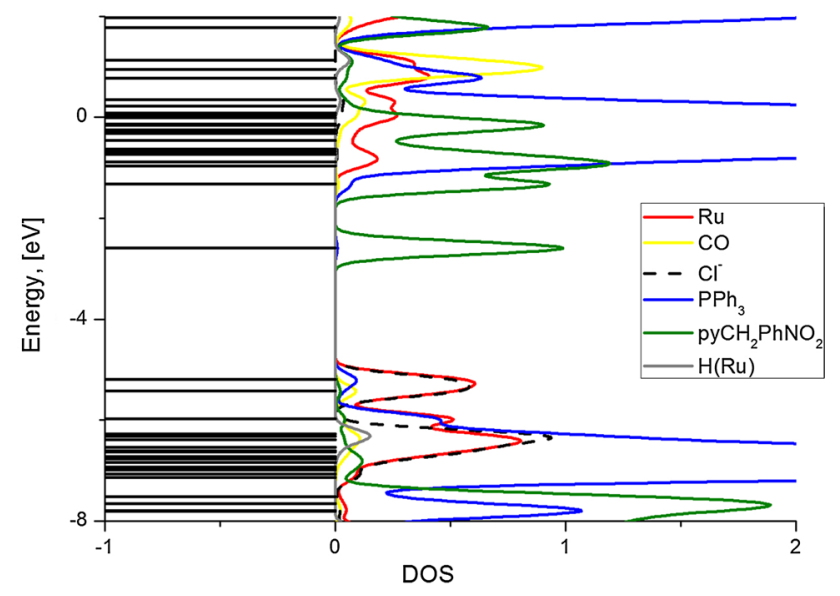

(1)

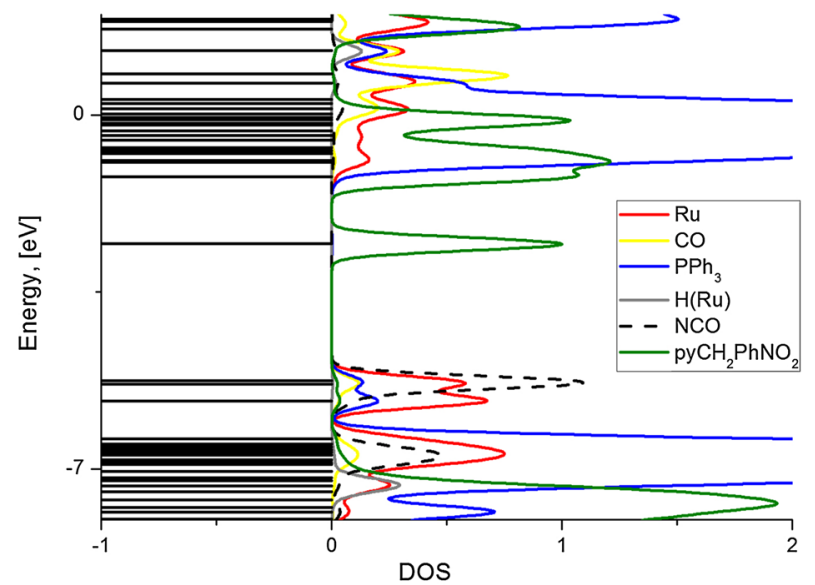

(2)

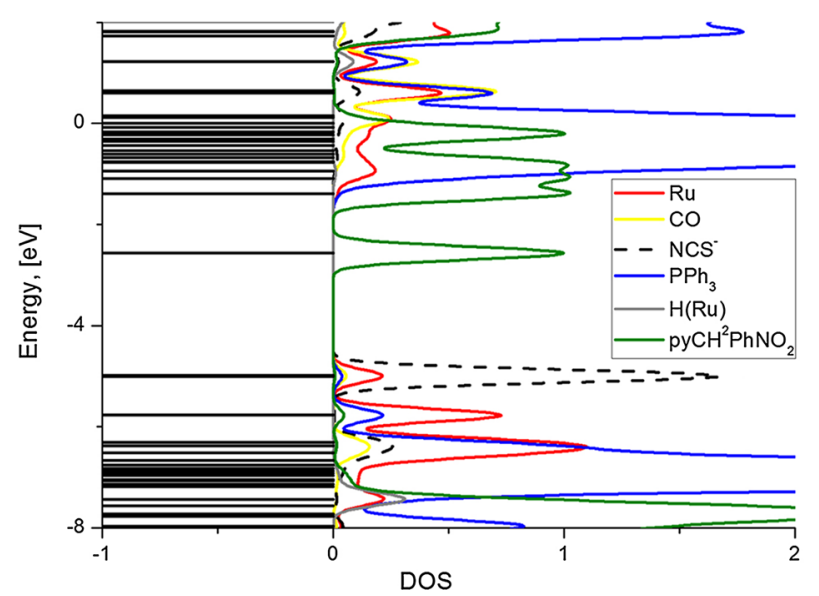

(3)

Fig. 2 DOS diagrams of complexes (1)-(3)

The structures of the complexes show intra- and intermolecular short contacts (Supplementary Materials, Table S1) which, according to Desiraju and Steiner, can be classified as weak hydrogen bonds [34]. Graph set analysis show that the hydrogen bonds do not create any additional structures. Moreover, analysis of the molecular arrangements in the crystal structures of these complexes indicates some electronic interactions between the pyridine and phosphine phenyl rings. Taking into account the mutual geometries of the rings (Supplementary Materials, Table S2), these can be considered as intramolecular $\pi \cdots \pi$ interactions.

\section{Quantum calculation}

The ground state geometries of the complexes were optimized in the singlet state, using the B3LYP functional. The calculations were carried out for the gas phase molecules, and in general, the calculated geometries are in agreement with the experimental data (see Table 2). The calculations on complex (1) were performed for the geometry of molecule $\mathrm{Ru}(2)$. The calculated bond lengths and angles are overestimated by about $0.1 \AA$ and $5^{\circ}$, which can be explained by the neglect of intermolecular interactions for the gas phase.

Based on the optimized geometries of the complexes, NBO analyses were performed in order to reveal the nature of the coordination between ruthenium and the donor atoms of the ligands. These analyses showed that the bonding between the 4-(4-nitrobenzyl)pyridine and ruthenium is largely noncovalent; the Coulomb-type interaction between the ruthenium center and 4-(4-nitrobenzyl)pyridine ligand is clearly visible in the calculated Wiberg bond indices, which are considerably lower than one, being equal to 0.3831 (1), 0.3418 (2) and 0.3422 (3). The Ru-P bond orders are also smaller than $1(0.7)$. The Wiberg indexes of the $\mathrm{CO}$ bonds in the complexes are reduced (by about 0.2 ) with respect to free $\mathrm{CO}$ $\left(\mathrm{W}_{\mathrm{CO}}=2.23\right)$. The maximum reduction of Wiberg index is calculated for complex (2), which is consistent with the lowest charge on the carbonyl ligand (0.171), while for complexes (1) and (3), the calculated natural charges on the carbonyl ligands are increased to 0.211 and 0.200 , respectively. However, the natural charges on ruthenium are lowest in complex (1) $(-0.911)$, whilst in the pseudohalide complexes, due to different configuration of equatorial plane, the values are close to -0.84 . The donations from the ligands to the metal have the advantage over the back donations from the metal to ligands, especially in the presence of strong $\pi$-acceptor carbonyl ligands; thus, the calculated natural charges are considerably lower than +2 .

Analysis of the frontier molecular orbitals is useful for understanding the spectroscopic properties such as electronic absorption and emission spectra. The partial density of state diagrams, presented in Fig. 2, shows a substantial share of $d_{\mathrm{Ru}}$ and chloride or pseudohalide orbitals in the HOMO. In complex (1), $d$-ruthenium and chloride contribute the 49 and $42 \%$, respectively, to the HOMO. In pseudohalide complexes (2) and (3), the 
Fig. 3 Contours of HOMO and LUMO in (1), (2) and (3) complexes

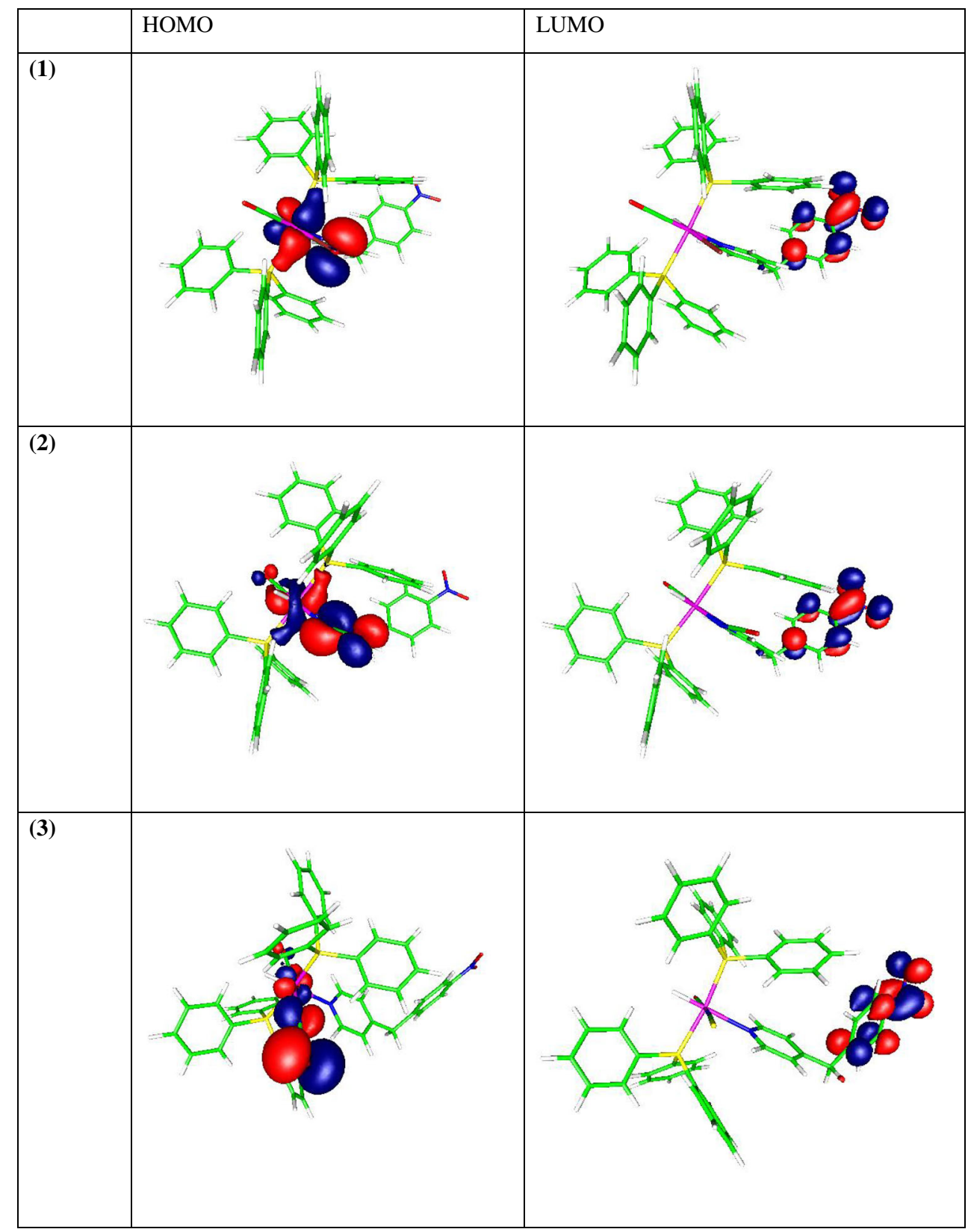

share of ruthenium decreases to 26 and $13 \%$, while the participation of $\mathrm{NCO}^{-}$and $\mathrm{NCS}^{-}$increases to 58 and $82 \%$, respectively. Moreover, in the HOMO's of the chloride and isocyanate complexes, as distinct from complex (3), the triphenylphosphine ligands take part (about $10 \%$ ). The ruthenium $d$ orbitals play substantial role, up to $73 \%$ for the isothiocyanate complex, in the MO's ranging from HOMO-1 to HOMO-3. The LUMOs of the complexes are localized on $\pi^{*}$ orbitals of 4-(4nitrobenzyl)pyridine, and for this reason, there are no significant differences in the energies of the LUMO in these complexes. The contours of the HOMO and LUMO of the complexes are presented in Fig. 3.
Electronic absorption and emission spectra

Experimental electronic absorption spectra of the complexes are presented in Fig. 4. There are two bands in the range 330-250 $\mathrm{nm}$ and a high energy band with maximum near $210 \mathrm{~nm}$ resulting from transitions in the $\mathrm{PPh}_{3}$ ligands and/or from $\pi \rightarrow \pi^{*}$ excitations in the $\mathrm{NO}_{2} \mathrm{PhCH}_{2}$ py ligand. This is also typical of other recently characterized hydride carbonyl ruthenium(II) complexes with pyridinetype ligands $[18,32]$. In the low energy region, weak bands above $300 \mathrm{~nm}$ were calculated transitions in which the HOMO, HOMO-1/-3 and LUMO, LUMO + 1, LUMO + 2 are engaged, and in accordance with the 


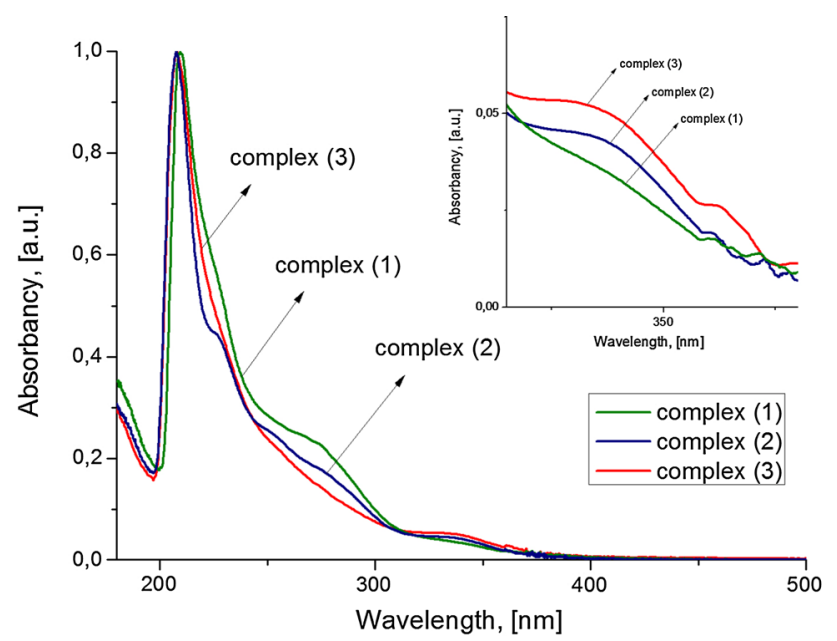

Fig. 4 Experimental absorption spectra of the (1)-(3) complexes. Inset graph: absorption band corresponding to the excitation wavelength

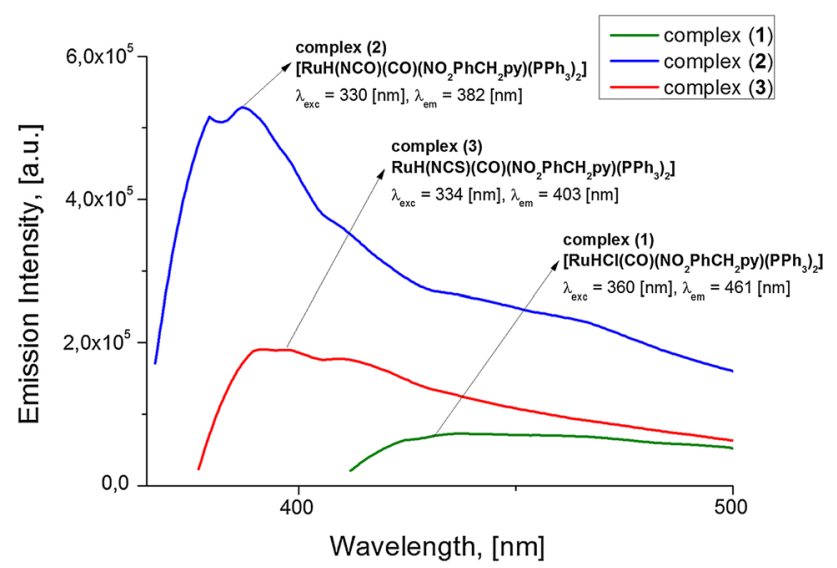

Fig. 5 Emission spectra of (1), (2) and (3) complexes

determined electronic structures of the complexes, the bands have Metal to Ligand Charge Transfer (MLCT) character with admixture of Ligand to Ligand Charge Transfer (LLCT). The bands in the vicinity of $250 \mathrm{~nm}$ can be described as LLCT transitions with small amount of MLCT character.

Under the same conditions as used for the complexes, the free $\mathrm{NO}_{2} \mathrm{PhCH}_{2}$ py ligand is nonemissive in excitation wavelengths between 250 and $500 \mathrm{~nm}$ (Supplementary Material, Figure S2). Moreover, the free ligand has recently been characterized as nonluminescent [35]. The solutions of the complexes excited at 360, 330 and $334 \mathrm{~nm}$ exhibit weak emission maxima at 461, 382 and $403 \mathrm{~nm}$, for complexes (1), (2) and (3), respectively. The photolumi- nescence (PL) spectra are shown in Fig. 5. The shift of the excitation and emission maxima to lower energy in the case of (1) may be connected with the comparatively higher participation of ruthenium in the occupied frontier orbitals. On the other hand, the determined Stokes shifts are equal to $4,578.92 \mathrm{~cm}^{-1}(\mathbf{1}), 4,125.02 \mathrm{~cm}^{-1}(\mathbf{2})$ and $5,126.22 \mathrm{~cm}^{-1}$ (3) and this parameter usually decreases with an increase of LLCT character in the excited state. Moreover, from the emission spectra, it can be seen that the PL intensity is the highest in the case of isocyanate complex (2); the quantum $\Phi_{\mathrm{em}}$ is $0.17 \%$. Complexes (1) and (3) show quantum yields under $0.01 \%$; thus, we can conclude that they are practically nonluminescent. Careful inspection of the calculated transitions close to the excitation energies shows substantial share of LLCT in the case of complex (2), which explains the value of the Stokes shift as well as the relatively high quantum yield. For complexes (1) and (3), however, the calculated transitions show increasing share of d-ruthenium orbitals (50 and $64 \%$, respectively); hence, the excited state can be characterized as MLCT admixture with LLCT. In Table 3, the selected calculated transitions and orbital compositions are presented. The photoluminescence lifetime measurements were made at room temperature using the time correlated single photon counting (TCSPC) method with excitation at $310 \mathrm{~nm}$ to eliminate solvent scattering. In each case, bi- or tri-exponential decay models were used to quantitatively fit the measured curves (Supplementary Materials, Figure S3). The longest lifetime was measured for the strongest emissive isocyanate complex (2) (see Table 4). The low quantum yields and short lifetimes for these complexes probably result from an easily obtained crossing point between the charge transfer state and MC state. This was confirmed by the calculation on the triplet state (spin density map), which indicated the localization of spin density on the ruthenium atom (Supplementary Materials, Figure S4).

\section{Conclusions}

A series of $\left[\mathrm{RuHX}(\mathrm{CO})\left(\mathrm{pyCHPhNO} \mathrm{CH}_{2}\right)\left(\mathrm{PPh}_{3}\right)_{2}\right]$ complexes, where $\mathrm{X}=\mathrm{Cl}, \mathrm{NCO}$, or NCS and pyCHPhNO${ }_{2}=4-(4-$ nitrobenzyl)pyridine, were obtained and structurally and spectroscopically characterized. The free pyridine derivative is known to be nonemissive, but its complexes reveal weak photoluminescence. The character of the excitation bands depends mostly on the character of the HOMOs, which are partially localized on $d$-ruthenium orbitals and chloride/pseudohalide ligands. Thus, the excitation transitions can be identified as having MLCT character with admixture of LLCT. The determined Stokes shifts, quan- 
Table 3 Selected calculated transitions and correspond orbitals compositions

\begin{tabular}{llll}
\hline Complex & Energy $(\mathrm{nm})$ & Transition & Orbital composition $\left(\mathrm{L}=\mathrm{pyCHPhNO}_{2}\right)$ \\
\hline$(1)$ & 375.4 & $\mathrm{H}-2 \rightarrow \mathrm{LUMO}(99 \%)$ & $\mathrm{Ru}(50 \%)+\mathrm{PPh}_{3}(42 \%) \rightarrow \mathrm{L}(99 \%)$ \\
& 360.2 & $\mathrm{HOMO} \rightarrow \mathrm{L}+2(69 \%)$ & $\mathrm{Ru}(49 \%)+\mathrm{Cl}(42 \%)+\mathrm{PPh}_{3}(9 \%) \rightarrow \mathrm{PPh}_{3}(19 \%)+\mathrm{L}(80 \%)$ \\
$(2)$ & 338.6 & $\mathrm{H}-3 \rightarrow \mathrm{LUMO}(95 \%)$ & $\mathrm{Ru}(23 \%)+\mathrm{PPh}_{3}(73 \%) \rightarrow \mathrm{L}(100 \%)$ \\
& 324.2 & $\mathrm{H}-4 \rightarrow$ LUMO $(56 \%)$ & $\mathrm{PPh}_{3}(92 \%) \rightarrow \mathrm{L}(100 \%)$ \\
$(3)$ & 337.5 & $\mathrm{H}-3 \rightarrow \mathrm{LUMO}(98 \%)$ & $\mathrm{Ru}(64 \%)+\mathrm{CO}(11 \%)+\mathrm{NCS}(19 \%) \rightarrow \mathrm{L}(100 \%)$ \\
& 324.1 & $\mathrm{HOMO} \rightarrow \mathrm{L}+2(65 \%)$ & $\mathrm{Ru}(13 \%)+\mathrm{NCS}(82 \%) \rightarrow \mathrm{L}(100 \%)$ \\
\hline
\end{tabular}

Table 4 Spectroscopic properties of the complexes

\begin{tabular}{lllllllll}
\hline Complex & $\lambda_{\mathrm{EX}}^{A}(\mathrm{~nm})$ & $\lambda_{\mathrm{EM}}^{A}(\mathrm{~nm})$ & $\Phi_{\mathrm{EM}}^{B}$ & $\tau_{\mathrm{EM}}^{C}(\mathrm{~ns})$ & $E_{\mathrm{G}}^{\text {OPT, d }}(\mathrm{eV})$ & $E_{\mathrm{G}}^{\mathrm{CALC}, \mathrm{e}}(\mathrm{eV})$ & $E_{\mathrm{HOMO}}^{E}(\mathrm{eV})$ & $E_{\mathrm{LUMO}}^{E}(\mathrm{eV})$ \\
\hline$(1)$ & 360 & 461 & $<0.0001$ & 6.9 & 2.88 & 3.11 & -5.68 & -2.58 \\
$(2)$ & 330 & 382 & 0.0017 & 7.5 & 3.25 & 3.08 & -5.65 & -2.57 \\
$(3)$ & 334 & 403 & $<0.0001$ & 4.8 & 3.08 & 3.22 & -5.77 & -2.56 \\
\hline
\end{tabular}

a Determined at $298 \mathrm{~K}$ in $\mathrm{MeOH}: \mathrm{EtOH}$ (1:4)

b Absolute quantum yields measured in $\mathrm{MeOH}: \mathrm{EtOH}(1: 4)$ mixture at room temperature

c Obtained by TSCPS method in optically diluted solutions (OD < 0.1) at $298 \mathrm{~K}$ in MeOH:EtOH (1:4) with excitation wavelength $340 \mathrm{~nm}$. Average values obtained from bi- or tri-exponential fitting measured curves

${ }^{\mathrm{d}}$ Estimated from emission maximum $E_{\mathrm{g}}^{\mathrm{opt}}=1,241 / \lambda_{\mathrm{em}}$

e Calculated at B3LYP/DZVP level

tum yields and lifetimes show that isocyanate complex has the strongest emissive nature, which is connected with substantial LLCT character of the fluorescence. However, the chloride and isothiocyanate complexes are practically nonemissive, with quantum yields under $0.01 \%$. The values of the lifetimes and low quantum yields are the characteristics of ruthenium(II) complexes, in which easily obtained ${ }^{3} \mathrm{MC}$ states impact on emissive MLCT/LLCT states.

\section{Supplementary Data}

CCDC 978367, 978365 and 978366 contain the supplementary crystallographic data for the complexes (1), (2) and (3), respectively. These data can be obtained free of charge via http://www.ccdc.cam.ac.uk/conts/retrieving. html or from the Cambridge Crystallographic Data Centre, 12 Union Road, Cambridge CB2 1EZ, UK; fax: +44 1223-336-033; or e-mail: deposit@ccdc.cam.ac.uk.

Acknowledgments The GAUSSIAN-09 calculations were carried out in the Wrocław Centre for Networking and Supercomputing, WCSS, Wrocław, Poland, http://www.wcss.wroc.pl.

Open Access This article is distributed under the terms of the Creative Commons Attribution License which permits any use, distribution, and reproduction in any medium, provided the original author(s) and the source are credited.

\section{References}

1. Wagenknecht PS, Ford PC (2011) Coord Chem Rev 255:591

2. Yersin H, Rausch AF, Czerwieniec R, Hofbeck T, Fischer T (2011) Coord Chem Rev 255:2622

3. Oner I, Sahin C, Varlikli C (2012) Dyes Pigm 95:23

4. Fantacci S, De Angelis F (2011) Coord Chem Rev 255:2704

5. Yin J-F, Velayudham M, Bhattacharya D, Lin H-C, Lu K-L (2012) Coord Chem Rev 256:3008

6. Takahashi Y, Arakawa H, Sugihara H, Hara K, Islam A, Katoh R, Tachibana Y, Yanagida M (2000) Inorg Chim Acta 310:169

7. Dosioa F, Stella B, Ferrero A, Garinob C, Zonari D, Arpicco S, Cattel L, Giordanoa S, Gobetto R (2013) Int J Pharm 440:221

8. Iizuka N, Motoki S, Nakai M, Nakabayashi Y (2014) Inorg Chem Commun 46:145

9. Huanga S, Zhu F, Qiua H, Xiao Q, Zhou Q, Su W, Hu B (2014) Colloids Surf, B 117:240

10. Ma J, Wu J, Liu W, Wang P, Fan Z (2012) Spectrochimica Acta Part A 94:340

11. Slim M, Sleiman HF (2004) Bioconjugate Chem. 15:949

12. Shan B-Z, Zhao Q, Goswami N, Eichhorn DM, Rillema DP (2001) Coord Chem Rev 211:117

13. Bomben PG, Robson KCD, Koivisto BD, Berlinguette CP (2012) Coord Chem Rev 256:1438

14. Tyson DS, Luman CR, Zhou X, Castellano FN (2001) Inorg Chem 40:4063

15. Pradhan B, Das S (2008) Chem Mater 20:1209

16. Wang P, Humphry-Baker R, Moser JE, Zakeeruddin SM, Grätzel M (2004) Chem Mater 16:3246

17. Stufkens DJ, Vlček A Jr (1998) Coord Chem Rev 177:127

18. Małecki JG, Krompiec S, Maroń A, Penkala M (2012) Polyhedron $48: 21$ 
19. Małecki JG, Maroń A, Gryca I, Mori A, Suzuki T (2013) Polyhedron 62:188

20. Ahmad N, Levinson JJ, Robinson SD, Uttely MF (1974) Inorg Synth 15:48

21. Gaussian 09, Revision A.1, M. J. Frisch, G. W. Trucks, H. B. Schlegel, G. E. Scuseria, M. A. Robb, J. R. Cheeseman, G. Scalmani, V. Barone, B. Mennucci, G. A. Petersson, H. Nakatsuji, M. Caricato, X. Li, H. P. Hratchian, A. F. Izmaylov, J. Bloino, G. Zheng, J. L. Sonnenberg, M. Hada, M. Ehara, K. Toyota, R. Fukuda, J. Hasegawa, M. Ishida, T. Nakajima, Y. Honda, O. Kitao, H. Nakai, T. Vreven, J. A. Montgomery, Jr., J. E. Peralta, F. Ogliaro, M. Bearpark, J. J. Heyd, E. Brothers, K. N. Kudin, V. N. Staroverov, R. Kobayashi, J. Normand, K. Raghavachari, A. Rendell, J. C. Burant, S. S. Iyengar, J. Tomasi, M. Cossi, N. Rega, J. M. Millam, M. Klene, J. E. Knox, J. B. Cross, V. Bakken, C. Adamo, J. Jaramillo, R. Gomperts, R. E. Stratmann, O. Yazyev, A. J. Austin, R. Cammi, C. Pomelli, J. W. Ochterski, R. L. Martin, K. Morokuma, V. G. Zakrzewski, G. A. Voth, P. Salvador, J. J. Dannenberg, S. Dapprich, A. D. Daniels, O. Farkas, J. B. Foresman, J. V. Ortiz, J. Cioslowski, D. J. Fox (2009) Gaussian, Inc., Wallingford CT

22. Becke AD (1993) J Chem Phys 98:5648
23. Lee C, Yang W, Parr RG (1988) Phys. Rev. B 37:785

24. Eichkorn K, Weigend F, Treutler O, Ahlrichs R (1997) Theor Chim Acc 97:119

25. Casida ME (1996) In: Seminario JM (ed) Recent developments and applications of modern density functional theory, theoretical and computational chemistry, vol 4. Elsevier, Amsterdam, p 391

26. O'Boyle NM, Tenderholt AL, Langner KM (2008) J Comp Chem 29:839

27. CrysAlis RED, Oxford Diffraction Ltd., Version 1.171.29.2

28. Dolomanov OV, Bourhis LJ, Gildea RJ, Howard JAK, Puschmann H (2009) J Appl Cryst 42:339

29. Sheldrick GM (2008) Acta Cryst. A 64:112

30. Małecki JG, Maroń A (2013) Transition Met Chem 38:133

31. Małecki JG, Maroń A (2013) Polyhedron 55:18

32. Małecki JG, Maroń A (2012) Transition Met Chem 37:727

33. Małecki JG, Maroń A (2012) Transition Met Chem 38:419

34. Desiraju GR, Steiner T (1999) The weak hydrogen bond in structural chemistry and biology. IUCr Monograph on Crystallography 9. Oxford University Press, Oxford

35. Chan C-W, Lai T-F, Che C-M, Peng S-M (1993) J Am Chem Soc $115: 11245$ 